\title{
PERHITUNGAN INVENTORI NUKLIDA PADA PIN BAHAN BAHAN REAKTOR PWR
}

\author{
Santo Paulus Rajagukguk ${ }^{1, *}$, S. Bakhri ${ }^{2}$, T. Surbakti ${ }^{2}$ \\ ${ }^{1}$ Jurusan Fisika, Fakultas Matematika dan Pengetahuan Alam (FMIPA), Universitas Negeri \\ Medan (UNIMED). Jl. William Iskandar Ps. V, Kenangan Baru, Kec. Percut Sei Tuan, \\ Kabupaten Deli Serdang, Sumatera Utara \\ ${ }^{2}$ Pusat Teknologi dan Keselamatan Reaktor Nuklir (PTKRN), BATAN, Gedung 80, Kawasan \\ Puspiptek, Tangerang Selatan, Banten \\ *email: Santopaulusrajagukguk98@gmail.com
}

\begin{abstract}
ABSTRAK
PERHITUNGAN INVENTORI NUKLIDA PADA PIN SEL BAHAN BAKAR REAKTOR

PWR. Perhitungan fisika reaktor untuk deplesi bahan bakar telah dilakukan, yang fokus pada inventori isotop $\mathrm{Pu}$ di dalam bahan bakar sisa. Perhitungan inventori isotop bahan bakar dilakukan dengan program komputer WIMSD-5B menggunakan data nuklir ENDFB-VII.1. Tujuan penelitian ini adalah untuk memprediksi jumlah atom $\mathrm{Pu}$ didalam bahan bakar selama reaktor dioperasikan 3 tahun. Nilai parameter fluks dihitung menggunakan program WIMSD dengan model pin bahan bakar yang terletak di zona bahan bakar aktif. Bahan bakar yang dimodelnya terdiri dari tipe A dan B. Hasil perhitungan faktor pelipatan tak hingga pin sel PWR yang dihitung menggunakan paket program WIMSD berturut-turut adalah 1,13614 dan 1,19171 untuk bahan bakar tipe A dan B. Dari hasil perhitungan dapat dinyatakan bahwa jumlah $\mathrm{Pu}$ yang tersisa tergantung pada model bahan bakar yang digunakan. Nilai faktor perkalian tak hingga juga sangat dipengaruhi oleh bentuk model bahan bakar yang digunakan.

Kata kunci: bahan bakar, teras PWR, WIMSD, fisika reaktor, faktor pelipatan tak hingga.
\end{abstract}

\section{ABSTRACT}

\section{CALCULATION OF NUCLIDE INVENTORIES FOR PIN CELL PWR REACTOR.}

Reactor physics calculations for fuel depletion were carried out, leading to an inventory of the $P u$ isotope in the residual fuel. The calculation of the fuel stockpile inventory was carried out by using the WIMSD-5B computer code and ENDFB-VII.1 nuclear data. The purpose of this study was to predict the number of $P u$ atoms in the fuel during the 3 year reactor operation. The value flux parameter value is calculated by the WIMSD with the fuel pin model located in the active fuel zone. The fuel model consists of types $A$ and $B$. The calculation results showed that the infinite multiplication factor of the PWR cell pins are 1.13614 and 1.19171 for fuel types $A$ and $B$, respectively. The amount of $P u$ remaining in the fuel depends on the fuel model used. The infinite multiplication factor value is also strongly influenced by the shape of the fuel model. Keywords: fuel, PWR core, WIMSD, reactor physics, infinite multiplication factor 


\section{PENDAHULUAN}

Program komputer WIMS adalah suatu perangkat lunak yang digunakan untuk menghitung deplesi isotop dalam bahan nuklir [1]. WIMS (Winfrith Improved Multigroup Scheme) adalah program komputer untuk perhitungan sel kisi reaktor pada berbagai sistem reaktor. Pada saat ini, pustaka data nuklir yang diperlukan (waktu paruh, penampang, hasil produk fisi, dll.) dan model reaktor (PWR-U, PWR-Pu, dan BWR) juga dikembangkan [2]. Program tersebut pada prinsipnya dimaksudkan untuk digunakan dalam menghasilkan tampang lintang (cross section) makroskopik bahan bakar bekas dan karakteristik limbah yang akan menjadi dasar untuk studi dan desain pabrik pengolahan ulang bahan bakar, kanister pengiriman bahan bakar bekas, fasilitas pengolahan dan pembuangan limbah, dan kanister pengiriman limbah. Setiap siklus operasi, bahan bakar diperiksa secara rutin, dengan demikian diharapkan dapat memahami berbagai karakteristik bahan bakar. Perhitungan dengan program WIMS adalah salah satu cara untuk memahami karakteristis bahan bakar yaitu inventori nuklida di dalam bahan bakar setelah diiradisi. Hasil yang diperoleh dengan hanya menyesuaikan integral resonansi dari bahan fisil dan fertil bahan bakar utama telah mendapatkan kesesuaian dengan komposisi bahan bakar bekas. Studi siklus bahan bakar sudah banyak dilakukan antaranya adalah studi dampak lingkungan yang membutuhkan perhitungan relatif tepat dari isotop minor seperti ${ }^{1} \mathrm{H},{ }^{14 \mathrm{C}},{ }^{232} \mathrm{U}$, ${ }^{242} \mathrm{Cm}$ dan ${ }^{244} \mathrm{Cm}[3,4]$.

Pada makalah ini dibahas deplesi bahan bakar pada model reaktor PWR uranium oksida atau uranium-plutonium oksida. Model PWR didasarkan pada desain Westinghouse dan program WIMSD [5] menggunakan cross section yang dihasilkan dari pengolahan kompilasi data nuklir yang sudah ada yaitu ENDFB.VII.1 [6]. Pembuatan informasi yang diperlukan untuk model reaktor ini dimulai dengan pengumpulan dan pemrosesan awal data penampang lintang yang ada dalam pustaka kelompok energi 69-neutron. Nuklidanuklida yang kehadirannya dalam reaktor akan memiliki efek terbesar pada spektrum neutron dan karakteristik deplesi dan perpustakaan yang lebih besar yang mengandung banyak nuklida yang menarik dalam kode WIMSD tetapi memiliki efek kecil pada spektrum dan deplesi bahan bakar. Tujuan penelitian ini adalah untuk mendukung program pemerintah dalam mengkaji keselamatan PLTN terutama PWR dalam hal perhitungan deplesi bahan bakar sel teras PWR berbahan bakar $\mathrm{UO}_{2}$ dan $\mathrm{PuO}_{2}$. 


\section{DESKRIPSI TERAS PWR}

Reaktor air bertekanan (PWR) adalah salah satu jenis reaktor nuklir dan sudah banyak digunakan untuk menghasilkan listrik terutama di Negara Negara maju seperti USA, Prancis, Cina, Korea dan Jepang [7]. PWR menggunakan air ringan $\left(\mathrm{H}_{2} \mathrm{O}\right)$ sebagai pendingin dan moderator neutron. PWR sudah digunakan untuk kesejahteraan manusia dan menjadikannya reaktor yang paling dominan di dunia. Reaktor PWR harus menggunakan uranium yang diperkaya sebagai bahan bakar nuklirnya, karena penggunaan air ringan sebagai pendingin dan moderatornya. Hal ini karena air ringan akan menyerap terlalu banyak neutron jika uranium alam digunakan, sehingga kandungan bahan bakar uranium-235 fisil harus ditingkatkan sehingga efektif. Hal ini dilakukan melalui proses pengayaan uranium, di mana konsentrasi Uranium-235 ditingkatkan dari 0,7\% menjadi sekitar 4\% [9]. Gambar 1 . menunjukkan perangkat bahan bakar $\mathrm{UO}_{2}$ PWR 17×17 yang tersusun dari 264 kisi sel bahan bakar dan 25 tabung pengarah [10]. Di dalam gambar tersebut tabung pengarah ditunjukkan dengan lingkaran yang putih, sedangkan pin bahan bakar adalah lingkaran yang gelap. Bentuk perangkat bahan bakar PWR berupa bujur sangkar simetris $90^{\circ}$ dengan ukuran $21,42 \mathrm{~cm} \times 21,42 \mathrm{~cm}$. Uranium yang diperkaya dikemas ke dalam batang bahan bakar (fuel rod) yang dirakit menjadi perangkat bahan bakar. Dalam satu perangkat bahan bakar fuel assembly, (FA), batang bahan bakar $\mathrm{UO}_{2}$ dan tabung pengarah (guide tube) disusun dalam 17×17. Tabung pengarah yang ada di tengah dipakai sebagai instrumentation guide thimbles. Gambar 2 menunjukkan teras PWR dengan 157 perangkat bahan bakar. Tabel 1 menyajikan data nuklir dan dimensi batang bahan bakar dan tabung pengarah di FA. Khusus material kelongsong ZIRLO, komposisi material dijelaskan dengan densitas $6,44 \mathrm{~g} / \mathrm{cm}^{3}$ dan komposisi nuklida adalah $1 \mathrm{w} \% \mathrm{Sn}, 1 \mathrm{w} \% \mathrm{Nb}, 0,1 \mathrm{w} \% \mathrm{Fe}$ dan sisanya $\mathrm{Zr}[10]$.

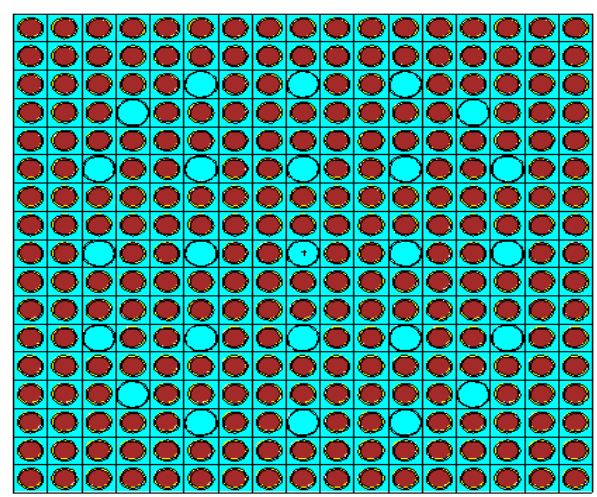

Gambar 1. Perangkat bahan bakar dan teras reaktor PWR [11] 


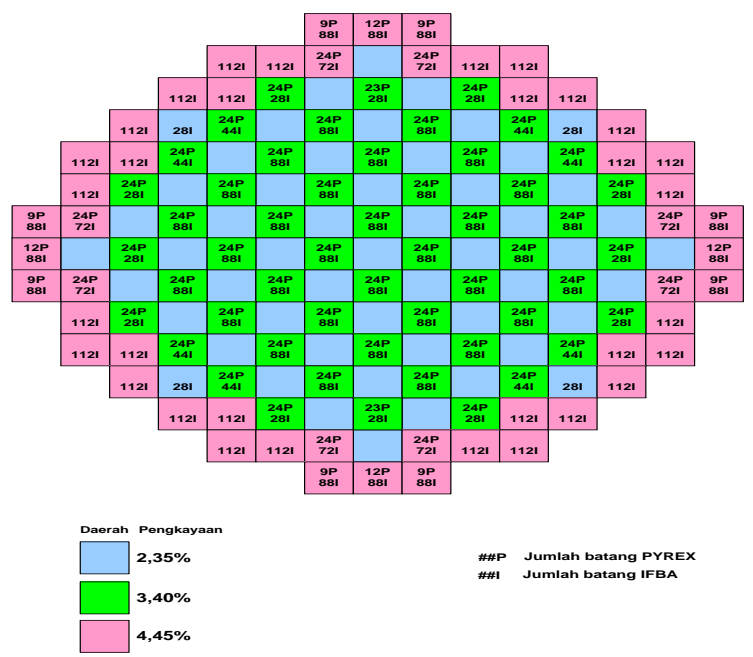

Gambar 2. Teras PWR dengan perangkat bahan bakar [12].

Tabel 1. Data nuklir bahan bakar teras PWR[13]

\begin{tabular}{ll}
\hline \multicolumn{1}{c}{ Parameter } & \multicolumn{1}{c}{ Keterangan } \\
\hline Pitch $(\mathrm{cm})$ & 1,3133 (square) \\
Moderator & $\mathrm{H}_{2} \mathrm{O}(+\mathrm{Bnat})$ \\
Temperatur moderator $(\mathrm{K})$ & 579 \\
Material bahan bakar & $\mathrm{UO}_{2}-\mathrm{PuO}_{2}$ \\
Temperatur bahan bakar $(\mathrm{K})$ & 933 \\
Radius pin bahan bakar $(\mathrm{cm})$ & 0,4095 \\
$\begin{array}{l}\text { Material kelongsong } \\
\text { Densitas atom kelongsong } \\
\text { (atoms/barn.cm) }\end{array}$ & $\mathrm{Zr}$ \\
Radius kelongsong (cm) & 0,043248 \\
Temperatur kelongsong $(\mathrm{K})$ & 0,4750 \\
\hline
\end{tabular}

\section{METODOLOGI}

Program WIMSD-5B dapat menghitung geometri bahan bakar batang (fuel rod) dalam susunan reguler dalam kelompok dan struktur energi neutron yang dipilih terutama untuk perhitungan termal. Pustaka dasar yang terdiri dari 60 group energy neutron telah membagi kedalam rentang energi 14 grup untuk energi neutron cepat, 13 grup untuk energi neutron resonansi, dan 42 grup untuk energi neutron termal [14], tetapi pengguna juga boleh memilih solusi akurat dalam banyak grup atau kalkulasi cepat dalam beberapa grup. Matriks hamburan termal tergantung suhu untuk hukum hamburan termasuk dalam library yang digunakan dalam WIMS terutama tumbukan dengan atom ringan pendingin/moderator air ringan $\left(\mathrm{H}_{2} \mathrm{O}\right)$. WIMSD-5B adalah versi terbaru dari program WIMS yang menggunakan data nuklir ENDFBVII.1 [15]. Perlakuan resonansi didasarkan pada penggunaan teorema ekivalensi dengan perpustakaan integral resonansi yang dievaluasi secara akurat untuk sistem homogen pada berbagai suhu. WIMS menggunakan teori tumbukan dalam perhitungan spektrum yang akurat pada 69 grup energi neutron. Kisi bahan bakar merupakan representasi geometris yang disederhanakan dari sel kisi yang dimodelkan berupa pin sel sepertiyang ditunjukan pada gamabar 3. Spektrum yang dihitung kemudian digunakan untuk kondensasi penampang lintang ke jumlah grup energi neutron yang dipilih dalam hal ini 69 grup untuk solusi persamaan transportasi dalam geometri sel kisi. Penyelesaian persamaan transport dilakukan dengan menggunakan metode Carlson DSN. Keluaran program WIMSD-5B memberikan nilai faktor multiplikasi neutron (k-inf), konstanta makroskopik dan inventori isotop bahan bakar setelah reaktor dioperasikan dengan tingkat fraksi bakar yang ditetapkan 50,0 GWd/tHM. Pemodelan 
pin sel bahan bakar PWR dilakukan dengan 2 kategori yaitu Degraded Plutonium Fuel = kasus A dan High Grade Plutonium Fuel = kasus B .

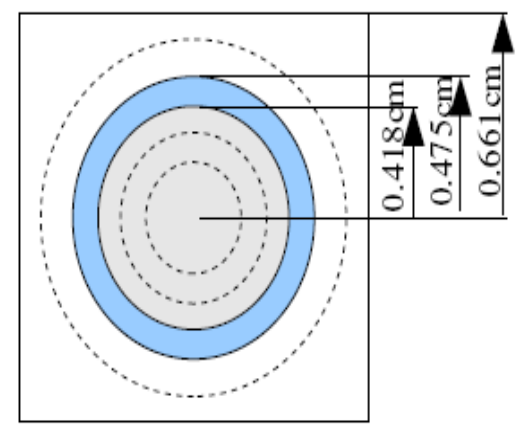

Gambar 3. Pemodelan input WIMSD-5B [16]

Perhitungan densitas atom bahan bakar $\left(\mathrm{UO} 2-\mathrm{PuO}_{2}\right) \mathrm{A}$ dan $\mathrm{B}$ dapat dilihat pada Tabel 2, sedangkan densitas atom untuk kelongsong dan pendingin dapat dilihat pada Tabel 3. Selain densitas atom bahan bakar A dan B juga ID program WIMSD-5B untuk setiap nuklida tersedia pada Tabel 2 dan 3. Dalam perhitungan ini temperatur untuk bahan bakar $933 \mathrm{~K}$ dan kelongsong diatur $579 \mathrm{~K}$ serta pendingin 579 K [17]. Nilai temperatur ini disesuaikan dengan temperatur bahan bakar dan kelongsong reaktor PWR

Tabel 2. Densitas atom bahan bakar PWR

\begin{tabular}{llll}
\hline Nuklida & $\begin{array}{l}\text { WIMS } \\
\text { ID }\end{array}$ & $\begin{array}{l}\text { Densitas A } \\
(/ \text { barn cm })\end{array}$ & $\begin{array}{l}\text { Densitas B } \\
(/ \text { barn cm })\end{array}$ \\
\hline${ }^{234} \mathrm{U}$ & 234.0 & - & $2,4626 \mathrm{E}-07$ \\
${ }^{235} \mathrm{U}$ & 2235.0 & $1,4456 \mathrm{E}-04$ & $5,1515 \mathrm{E}-05$ \\
${ }^{238} \mathrm{U}$ & 8238.0 & $1,9939 \mathrm{E}-02$ & $2,0295 \mathrm{E}-02$ \\
${ }^{238} \mathrm{Pu}$ & 948 & $1,1467 \mathrm{E}-04$ & $2,1800 \mathrm{E}-05$ \\
${ }^{239} \mathrm{Pu}$ & 6239 & $1,0285 \mathrm{E}-03$ & $7,1155 \mathrm{E}-04$ \\
${ }^{240} \mathrm{Pu}$ & 1240 & $7,9657 \mathrm{E}-04$ & $2,7623 \mathrm{E}-04$ \\
${ }^{241} \mathrm{Pu}$ & 1241 & $3,3997 \mathrm{E}-04$ & $1,4591 \mathrm{E}-04$ \\
${ }^{242} \mathrm{Pu}$ & 1242 & $5,6388 \mathrm{E}-04$ & $4,7643 \mathrm{E}-05$ \\
${ }^{16} \mathrm{O}$ & 6016 & $4,5851 \mathrm{E}-02$ & $4,3100 \mathrm{E}-02$ \\
\hline
\end{tabular}
dengan fraksi bakar yang sama akan menghasilkan nilai k-inf yang hampir sama. Saat reaktor beroperasi terjadi pembakaran uranium dan plutonium sebagai bahan bakar, dengan berkurangnya jumlah uranium dan plutonium maka nilai k-inf juga menurun.

\begin{tabular}{llll}
\hline Nuklida & $\begin{array}{l}\text { WIMS } \\
\text { ID }\end{array}$ & $\begin{array}{l}\text { Densitas atom } \\
(/ \text { barn cm })\end{array}$ & $\begin{array}{l}\text { Temperatur } \\
(\mathrm{K})\end{array}$ \\
\hline $\mathrm{Zr}$ & 91 & $4,3248 \mathrm{E}-02$ & 579 \\
$\mathrm{H}$ & 3001 & $4,7716 \mathrm{E}-02$ & \\
$\mathrm{O}$ & 6016 & $2,3858 \mathrm{E}-02$ & 579 \\
$\mathrm{~B}$ & 1011 & $1,98606 \mathrm{E}-05$ & \\
\hline
\end{tabular}

\section{HASIL DAN PEMBAHASAN}

Setelah melakukan perhitungan dengan menggunakan program WIMSD-5B, hasil yang diperoleh dapat dilihat pada Gambar 4 yaitu nilai k-inf bahan bakar A dan B. Nilai k-inf awal untuk 69 grup energi neutron adalah 1,13614 untuk bahan bakar A dan 1,19171 untuk bahan bakar B. Hal ini karena jumlah U-235 pada bahan bakar B lebih besar dari bahan bakar A. Pada Gambar tersebut terlihat perbedaan profil nilai k-inf bahan bakar A dan B seiring dengan terjadinya defleksi pada bahan bakar hingga fraksi bakar 50,0 MWd/tHM. Densitas atom kedua bahan bakar A dan B berbenda, namun pada akhir siklus yaitu Cengan fraksi bakar yang sama akan 


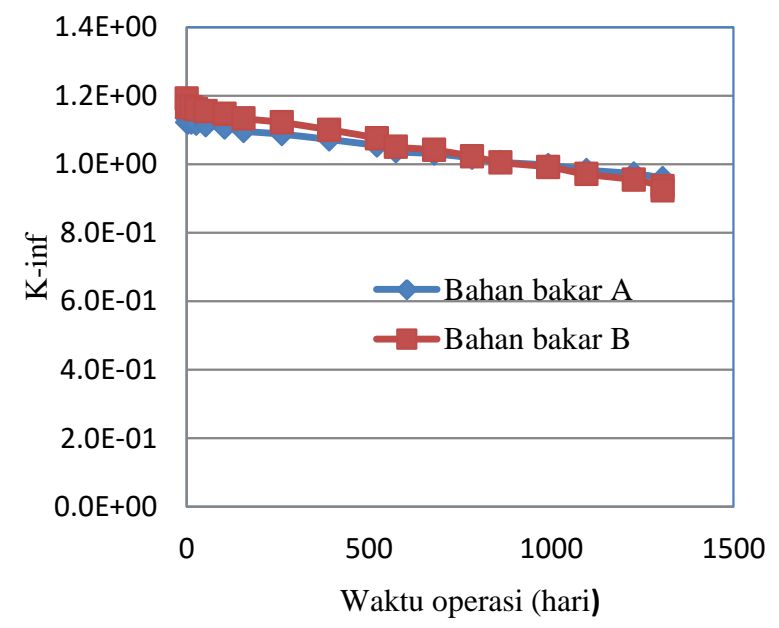

Gambar 4. Nilai k-inf untuk bahan bakar A dan B

Nilai fraksi bakar untuk bahan bakar A dan B dapat dilihat pada Gambar 5. Saat reaktor beroperasi maka bahan bakar terus dibakar dengan menembakkan neutron termal ke material uranium dan plutonium sehingga lama kelamaan jumlah bakar bakar menurun namun nilai fraksi bahan bakar meningkat hal ini sering disebut dengan fuel utilization. Fraksi bakar dalam PLTN (Pembangkit Listrik Tenaga Nuklir) sering menggunakan satuan GWd/tHM. Hal ini menyatakan jumlah energi yang dihasilkan selama waktu rraktor PWR beroperasi normal. Jumlah energi yang dibangkitkan oleh PLTN PWR semakin baik apabila jumlah energinya semakin besar. Dalam penelitian ini fraksi bakar dihitung dengan menggunakan proram WIMSD-5B hingga 50.0 GWD/tHM dengan waktu 1096 hari.

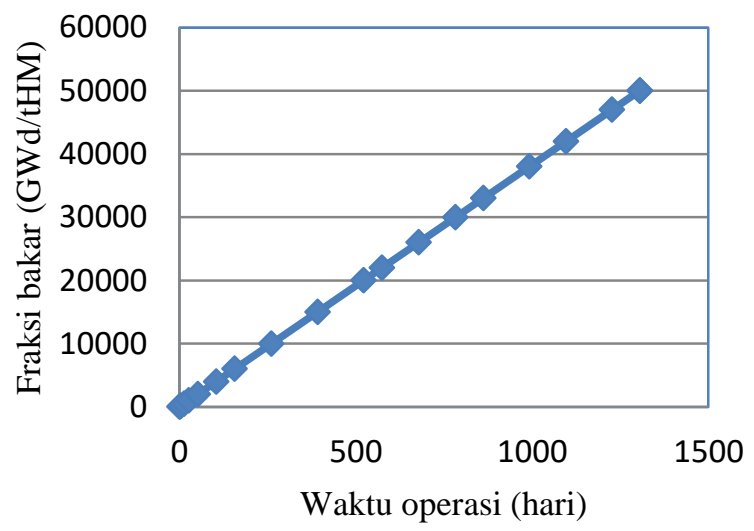

Gambar 5. Fraksi bakar baha bakar A dan B

Gambar 6 adalah hasil perhitungan program WIMSD-5B untuk nilai fluks neutron total bahan bakar A dan B. Fluks neutron total pada bahan bakar merupakan gabungan dari seluruh fluks neutron dari energi cepat sampai termal. Fluks neutron total tergantung pada jumlah bahan bakar (uranium dan plutonium) di dalam bahan bakar, sehingga semakin lama dibakar maka (fraksi bakar tinggi) fluks neutron total semakin meningkat namun dalam PLTN fluks neutron tidak digunakan untuk riset. Jelas kelihatan bahwa jika jumlah uranium berkurang akibat deflesi bahan bakar maka fluks neutron total naik seiring dengan waktu operasi. Fluks neutron total yang dihasilkan dalam orde $10^{14}$. Hasil perhitungan ini sudah sesuai dengan referensi [18]. 


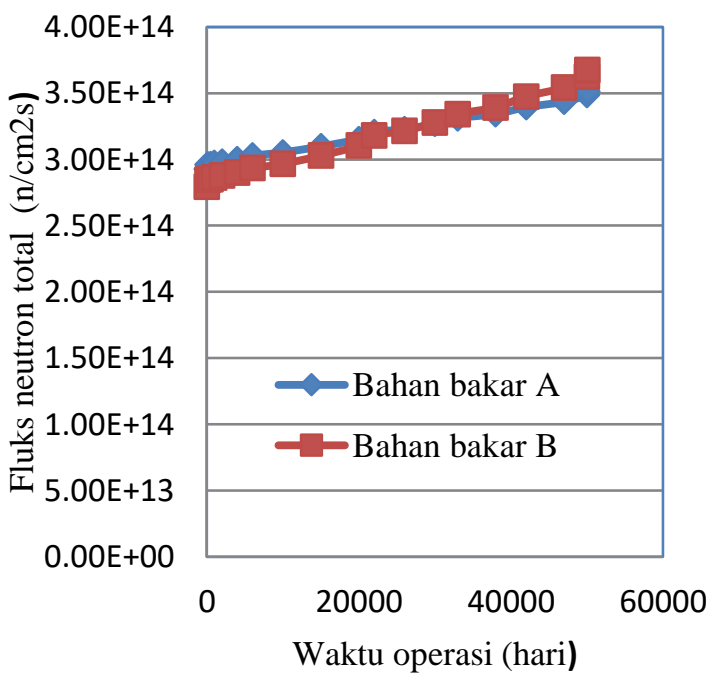

Gambar 6. Fluks neutron total bakar bakar A dan B

Gambar 7 adalah hasil perhitungan fluks neutron cepat pada bahan bakar A dan B. Neutron cepat juga naik ketika jumal uranium dan plutonium dalam baban bakar berkurang.

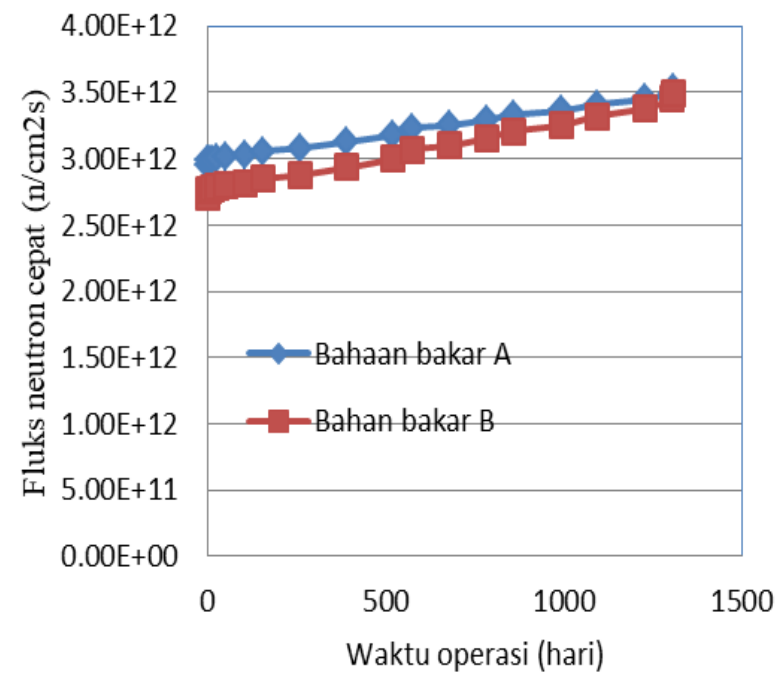

Gambar 7. Fluks neutron cepat bakar bakar A dan B

Jelas terlihat pada Gambar 7 bahwa fluks neutron cepat antara bahan bakar A dan B berbeda, hal ini disebabkan karena densitas atom bahan bakar berbeda. Fluks neutron cepat dihasilkan dalam perhitungan ini adalah dalam orde $10^{12}$.

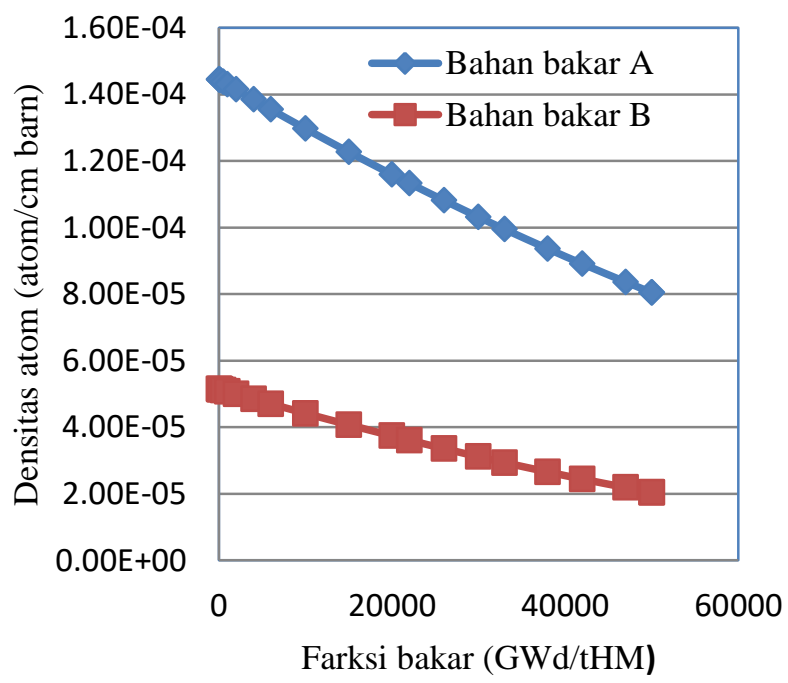

Gambar 8. Densitas U-235 bahan bakar A dan B

Densitas U-235 pada bahan bakar A dan B dapat dilihat pada Gambar 8. Densitas U-235 menurun seiring dengan waktu operasi. Pada Gambar 8 ditunjukan bahwa pada keadaan awal jumlah U-235 pada bahan bakar A lebih besar dari bahan bakar B dan selama pembakaran di teras reaktor juga dapat dilihat bahwa jumlah U-235 pada bahan bakar A juga lebih besar dari bahan bakar B sampai akhir siklusnya. Nuklida U-235 akan berfisi jika ditembak neutron termal dan menghasilkan produk fisi, energi panas dan neutron. Untuk bahan bakar A U235 yang berkurang sekitar 44,3 \% sedangkan pada bahan bakar B 60,4 \% . 


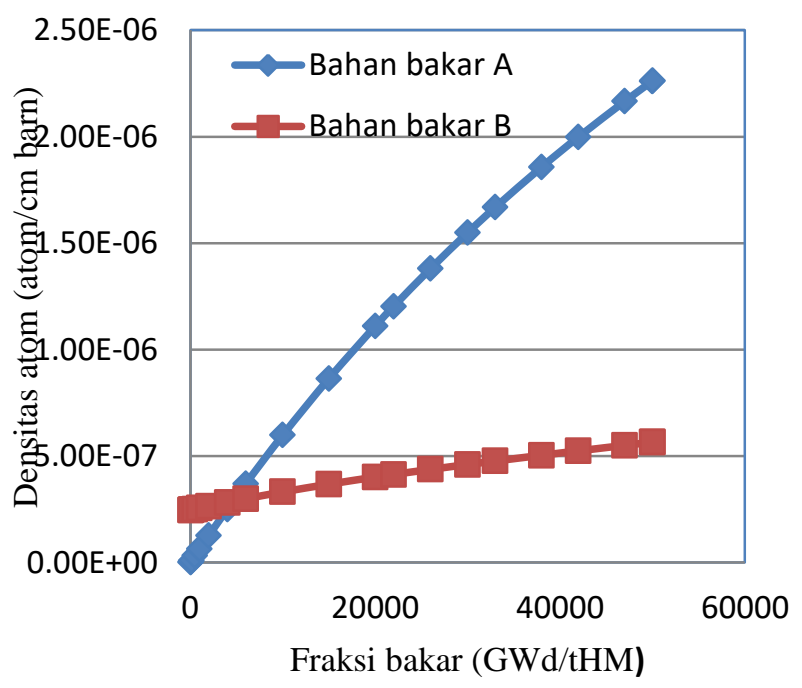

Gambar 9. Densitas U-234 fungsi fraksi bakar

Pada Gambar 9 ditunjukan densitas

U-234 pada bahan bakar A dan B hasil perhitungan WIMSD-5B. Densitas U-234 naik seiring dengan adanya reaksi penangkapan neutron dan pelepasan partikel pada bahan bakar A dan B. Pada Gambar 9 ditunjukan bahwa peningkatan densitas U234 pada bahan bakar A lebih besar dari bahan bakar B. Pada bahan bakar A awalnya tidak ada nuklida U-234 namun dihasilkan seiring terjadi reaksi fisi dan reaksi tangkapan serta pelepasan partikel dari inti atom U-238 di dalam teras.

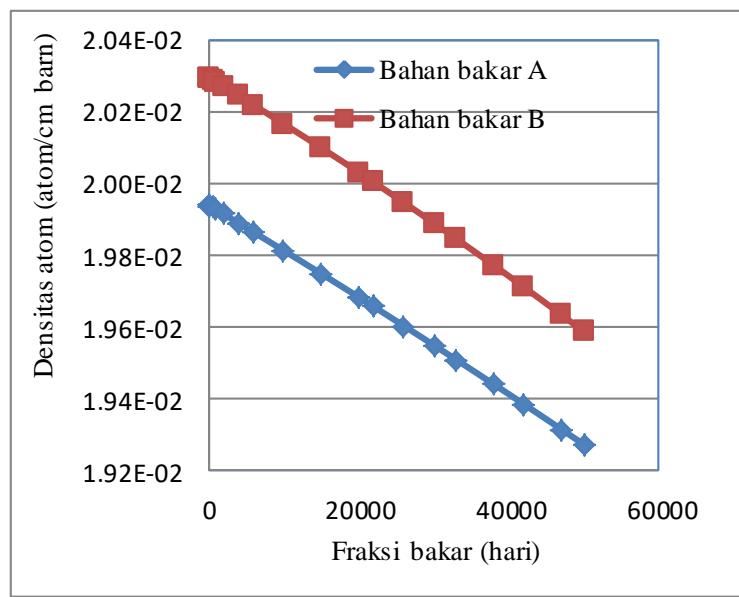

Gambar 10. Densitas U-238 fungsi fraksi bakar

Pada Gambar 10 ditunjukan hasil perhitungan densitas atom U-238 pada bahan bakar A dan B. Jumlah densitas atom U-238 pada bahan bakar A dan B tidak sama pada awalnya dan demikian juga pada akhir siklus tidak sama jumlahnya namun kecendungannya atau kemiringan grafik yang dihasilkan adalah sama. Hal ini menunjukkan bahwa derajat pembakaran U238 di dalam teras untuk bahan bakar A dan B adalah sama.

Gambar 11 menunjukkan nilai densitas U-236 hasil perhitungan program WIMSD-5B untuk bahan bakar A dan B. Pada awalnya densitias atom U-236 pada bahan bakar A dan B tidak ada atau nol. Namun seiring dengan adanya reaksi tangkapan neutron dan pelepasan partikel maka densitas atom uranium-236 terbentuk di bahan bakar A dan B. 


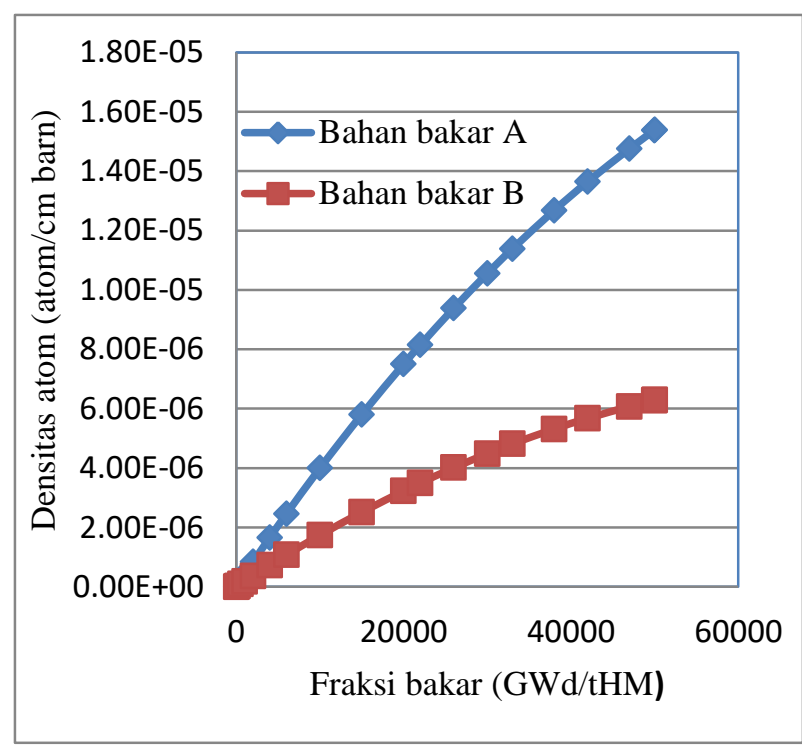

Gambar 11. Densitas U-236 fungsi fraksi bakar

Gambar 11 menunjukkan bahwa jumlah densitas atom U-236 diakhir siklus tidak sama yaitu lebih besar dibahan bakar A. Hal ini disebabkan oleh karena jumlah U-235 bahan bakar A lebih besar dari bahan bakar B. U-236 dibentuk sebagian besar dari U-235 dan Pu-238.

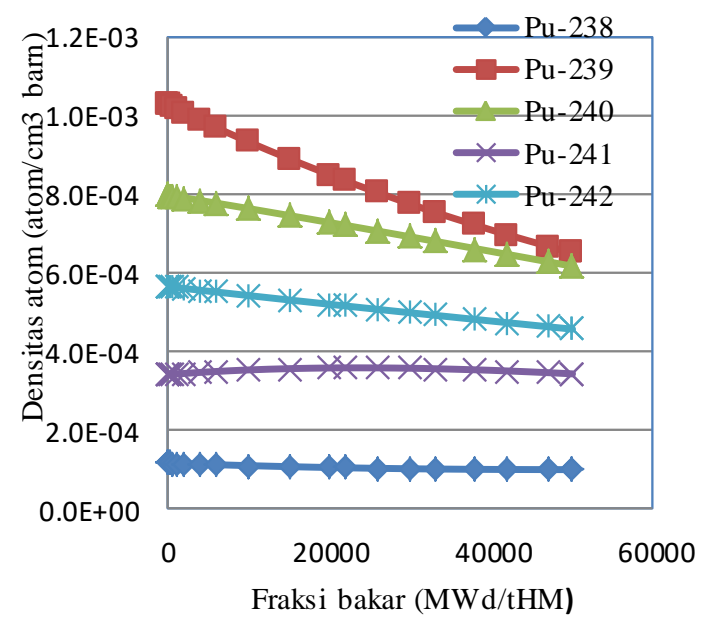

Gambar 12. Densitas atom Pu bahan bakar A fungsi fraksi bakar

Gambar 12 menunjukkan hasil perhitungan inventori nuklida $\mathrm{Pu}$ pada bahan bakar A. Hasil perhitungan menunjukkan bahwa jumlah densitas ke 5 atom $\mathrm{Pu}\left({ }^{238-}\right.$
${ }^{242} \mathrm{Pu}$ ) di bahan bakar A. Densitas atom $\mathrm{Pu}$ semuanya menurun seiring dengan meningkatnya fraksi bakar. $\mathrm{Pu}-239$ yang paling besar menurunnya sekitar 36,8\% dibanding dengan $\mathrm{Pu}$ yang lain karena tampang lintang serapan Pu-239 lebih besar dibanding Pu yang lain.

Profil isotop inventori atom $\mathrm{Pu}$ bahan bakar B dapat dilihat pada Gambar 13. Pada bahan bakar B juga diperoleh kecendrungan yang sama, paling besar $\mathrm{Pu}-239$ yang dibakar sekitar 57,7\% sehingga grafiknya lebih curam dibanding bahan bakar A.

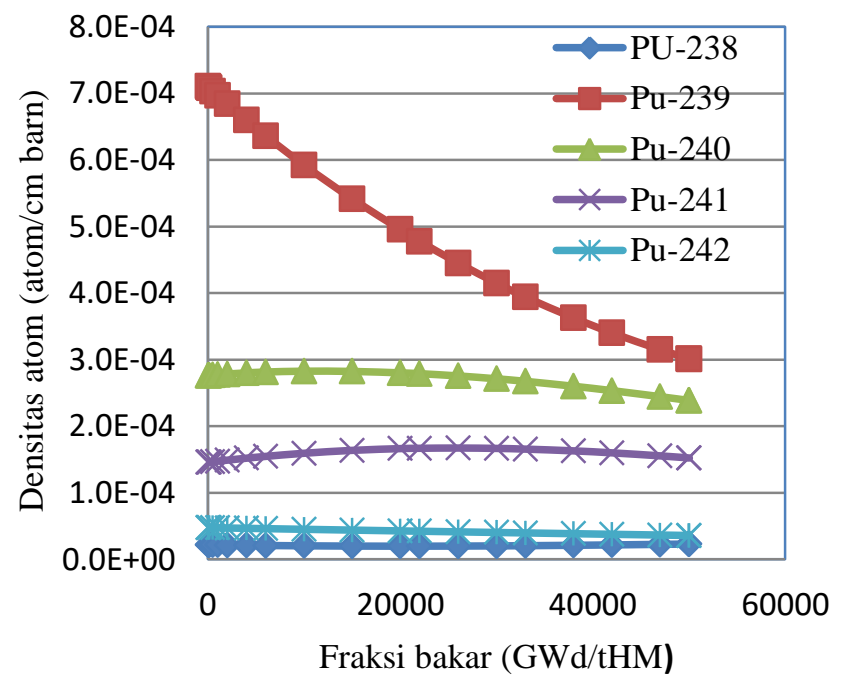

Gambar 13. Densitas atom Pu bahan bakar B fungsi fraksi bakar

\section{KESIMPULAN}

Perhitungan inventori nuklida bahan bakar teras PWR dengan program WIMSD5B menggunakan model pin sel telah dilakukan. Parameter sel bahan bakar dengan 69 grup energi neutron, tipe bahan bakar A dan B mempunyai perbedaan yang 
signifikan yaitu masing masing menghasilkan nilai k-inf 1,13614 dan 1,19171. Hasil perhitungan menunjukankan bahwa profil inventori isotop $\mathrm{Pu}$ menurun semua untuk bahan bakar A dan B. Untuk bahan bakar A U-235 yang berkurang sekitar 44,3\% sedangkan pada bahan bakar B 60,4 \% sedangkan Pu-239 untuk bahan A hanya $36,8 \%$ sedangkan untuk bahan bakar B 57,7\%. Hal ini masih memenuhi syarat dan masih di bawah standar plutonium yang diijinkan selama pembakaran dalam teras reaktor PWR.

\section{UCAPAN TERIMAKASIH}

Penelitian ini selesai dilakukan berkat pertolongan para peneliti. Kami mengucapkan terimakasih kepada koordinator bidang BFTR dan kepada Pusat PTKRN yang telah memberikan kesempatan untuk melakukan penelitian ini dan melakukan tugas akhir di PTKRN.

\section{DAFTAR PUSTAKA}

[1]. T. SURBAKTI, S. PINEM, T. M. SEMBIRING, "Analisis Pengaruh Densitas Bahan Bakar Silisida Terhadap Parameter Kinetik Teras Reaktor RSG-GAS", Jurnal Penelitian Fisika dan Aplikasinya. 2013; 3(1): 19-30.

[2]. S. PINEM, T. SURBAKTI, "Analysis on Neutronic Parameters of the AP1000 Reactor Core", Prosiding Seminar Nasional Teknologi Energi Nuklir 2016, 569-576.
[3]. S. PINEM, P. H. LIEM, T. M. SEMBIRING, T. SURBAKTI, "Fuel Element Burn-up Measurements for the Equilibrium LEU Silicide RSG GAS (MPR-30) Core under a New Fuel Management Strategy", Ann. Nucl. Energy, vol. 98, 2016.

[4].T. SURBAKTI, S. PINEM, “Analisis Perhitungan Desain Teras PWR pada Konfigurasi Kritis dengan SCALE5.1" Prosiding Seminar Nasional Teknologi Energi Nuklir serta Fasilitas Nuklir 2010.

[5].T. SURBAKTI., "Optimalisasi Bahan bakar MOX pada Desain Teras AP1000" Proceedings of the National Seminar on Nuclear Energy Technology serta Fasilitas Nuklir 2013, 24-25 September 2013, Yogyakarta.

[6]. T. M. SEMBIRING, "Penggunaan Paket Program WIMSD/5B.12 dan BATAN-2DIFF untuk RSG-GAS," PRSG, April, 2011.

[7]. S. PINEM, T. SURBAKTI, "Analysis on Neutronic Parameters of the AP1000 Reactor Core", Prosiding Seminar Nasional Teknologi Energi Nuklir 2016, 569-75

[8]. S. TUKIRAN, IMAN KUNTORO, "Analisis Karakteristik Perangkat Bahan Bakar Maju Teras PWR", Proseding Seminar Nasional ke-16 Teknologi dan Keselamatan PLTN serta Fasilitas Nuklir, ITS, Surabaya, 2010.

[9]. S. PINEM, T. M. SEMBIRING, T. SURBAKTI, "Neutronic Parameters Analysis of a PWR Fuel Element using Silicon Carbide Claddings with SRAC2006/NODAL3 Codes", The 3rd International Conference on Nuclear Energy Technologies and Sciences (ICoNETS) 2019 AIP Conf. Proc. 2180, 020003-1-020003-10.

[10]. S. PINEM, TM. SEMBIRING, T. SURBAKTI, "PWR Fuel Macroscopic Cross Section Analysis for Calculation Core Fuel Management Benchmark" 2019 J. Phys.: Conf. Ser. 1198. 
[11]. S. PINEM, TM. SEMBIRING, T. SURBAKTI, "Analysis on Neutronic Pparameters of the AP1000 Reactor Core", Proceedings of the National Seminar on Nuclear Energy Technology 2016, 4-5 August 2016, Batam.

[12]. S. PINEM, TM SEMBIRING, T SURBAKTI, "Verifikasi Program PWR-FUEL Dalam Manajemen Bahan Bakar PWR", Jurnal Sains dan Teknologi Nuklir Indonesia (Indonesian Journal of Nuclear Science and Technology) 2015, (16), 53-62.

[13]. T SURBAKTI, M IMRON, "Fuel Burn-up Calculation for Working Core of the RSG-GAS Research Reactor at BATAN Serpong", Jurnal Penelitian Fisika dan Aplikasinya (JPFA) 7 (2), 89-101.

[14]. S. PINEM, T M. SEMBIRING, T. SURBAKTI, DESWANDRI, GENI RINA"Reactivity Coefficient Calculation for AP1000 Reactor Using the NODAL3 Code" International Conference on Nuclear Technologies and Sciences (ICoNETS 2017) IOP Publishing IOP Conf. Series: Journal of Physics: Conf. Series 962 (2018) 012057.

[15]. T SURBAKTI, P PURWADI, "Analysis of Neutronic Safety Parameters of the Multi-Purpose
Reactor-Gerrit Augustinus Siwabessy (RSG-GAS) Research Reactor at Serpong", Jurnal Penelitian Fisika dan Aplikasinya (JPFA) 9 (1), 78-91.

[16]. I. KUNTORO, S. PINEM, TM. SEMBIRING, T. SURBAKTI, "Evaluation of Fuel Loading Pattern of PWR Core using PWR-FUEL C

[17]. ode", The 3rd International Conference on Nuclear Energy Technologies and Sciences (ICoNETS) 2019 AIP Conf. Proc. 2180, 020007-1-020007-9.

[18]. S. TUKIRAN ET AL. Calculation of PWR Thorium Pin Cell Burnup and Isotope Prediction Using WIMSD-5B Code. 2021 J. Phys.: Conf. Ser. 1811 012047.

[19]. A. HAMZAH, "Analisis Distribusi Fluks dan Spektrum Neutron Reaktor PLTN PWR 1000 MWe Menggunakan Program MCNP", Prosiding Seminar Nasional ke-18 Teknologi dan Keselamatan PLTN Serta Fasilitas Nuklir, Bandung 2012 